\title{
Protection of Traditional Knowledge: The Work and the Role of International Organisations and Conferences
}

\author{
Asiia Sharifullovna Gazizova ${ }^{1}$ \\ ${ }^{1}$ Junior Researcher of Research and Educational Center for Human Rights, International Law and Problems of \\ Integration, Faculty of Law, Kazan Federal University, Russia \\ Correspondence: Asiia Sharifullovna Gazizova, Junior Researcher of Research and Educational Center for Human \\ Rights, International Law and Problems of Integration, Faculty of Law, Kazan Federal University, Russia. E-mail: \\ asiia.gazizova@yahoo.com
}

Received: September 10, 2020

Accepted: October 26, 2020

Online Published: October 31, 2020

doi:10.5430/ijhe.v9n8p95

URL: https://doi.org/10.5430/ijhe.v9n8p95

\begin{abstract}
The concepts of traditional knowledge, indigenous people and indigenous knowledge have gained broad use in international discussions on sustainable improvement. Nevertheless, their use is usually subjected to confusion. There have been numerous attempts to clarify the notions of traditional knowledge, indigenous knowledge and people. Although there are no globally approved definitions, this paper is devoted to analysing the approaches of international organisations to the protection of traditional knowledge. The study discusses the work of the international organisations: WIPO, UNESCO, WHO, WTO and FAO, as well as international conferences: Conference of the Parties of Convention on Biological Diversity and UNCTAD. The examples of traditional knowledge illustrate the paper: use of turmeric for wound healing in India, use the Hoodia plant to suppress hunger during hunting in South Africa and others. It is noted that today, at the international level, there are no instruments that ensure comprehensive protection of traditional knowledge. The author concludes that WIPO and UNESCO currently carry out the main work aimed at providing the protection of traditional knowledge. However, other international organisations and conferences, such as WHO, WTO, FAO, UNCTAD and Conference of the Parties of CBD in their work are also addressed some aspects associated with the preservation of traditional knowledge.
\end{abstract}

Keywords: traditional knowledge, WIPO, UNESCO, WHO, WTO, FAO, UNCTAD

\section{Introduction}

Undoubtedly, traditional knowledge is a foundation of knowledge, know-how, and practices promoted and preserved by local society and conveyed from generation to generation in the community. Traditional knowledge is observed in a wide variety of fields. For instance, it can be knowledge concerning sustainable management of natural resources; knowledge associated with traditional architecture and traditional building technologies; knowledge related to traditional music, art, traditional methods of producing and utilising instruments; medical knowledge and knowledge associated with the use of plants, herbs, minerals and animals; traditional hunting and tracking skills; conventional models of nature conservation and biodiversity conservation.

Particular instances of traditional knowledge include:

- The application of turmeric for wound healing in India (Gazizova, 2019);

- Eating the Hoodia plant to suppress hunger while hunting by representatives of the San people living in South Africa (Wynberg \& Chennells, 2009);

- Application of traditional methods of cattle breeding in Mongolia (Badaraev, 2016: Stepanova et al, 2019).

There is now no internationally admitted description of ancient knowledge. Some international treaties include provisions on traditional knowledge and/or references to traditional knowledge. Article 8 (j) of the Convention on Biological Diversity refers to "the knowledge, practices and innovations of local and indigenous societies reflecting ancient lifestyles that are related to the protection and constant usage of biological diversity". The Nagoya Protocol on Access to Genetic Resources and the Fair and Equitable Sharing of Benefits Arising from their Utilisation refers 
to "traditional knowledge connected with genetic sources". Article 9.2 of the International Treaty on Plant Genetic Resources for Food and Agriculture deals with the protection of traditional knowledge related to plant genetic resources for food and agriculture (Halupa, \& Caldwell, 2015).

\section{Methods}

The main methods used in the research are the specific historical, comparative-legal and systemic methods.

\section{Results and Discussion}

The main work in the field of the international legal protection of traditional knowledge and traditional cultural expressions is carried out within the framework of such international organisations like the World Intellectual Property Organization (WIPO) and the United Nations Educational, Scientific and Cultural Organization (UNESCO).

\subsection{WIPO}

WIPO is directly developing a global legal tool that will guarantee the preservation of traditional understanding, cultural expressions and genetic resources at the international level. This was the challenge for the WIPO Intergovernmental Committee on Intellectual Property and Genetic Resources, Traditional Knowledge and Folklore established in 2000. The Committee has developed several versions of definitions of traditional knowledge, has defined criteria for its protection, outlined the range of beneficiaries, scope and conditions of safety, and also proposed to introduce certain sanctions and remedies to combat the misappropriation and misuse of traditional knowledge (WIPO, 2019).

The Committee carried out extensive work and made considerable efforts to develop a document that can ensure effective protection of traditional knowledge. However, in the process of agreeing with the opinions of states regarding the protection of these objects, certain difficulties arose.

Firstly, there is a lack of clarity about the nature of the document being drafted. Will it be a legally binding document, as most developing countries want, or will it be a flexible international document that is not binding, as the US, EU, Russia, and a number of other states wish to?

Secondly, the question of the number of documents being developed remains unresolved: should it be one document combining the protection of genetic resources, traditional knowledge and traditional cultural expressions, or three separate independent documents?

Thirdly, there is disagreement as to whether protection should be provided within the intellectual property system or under a human rights approach. If the choice is made in favour of intellectual property, then the question arises about the application of existing intellectual property rights or the development of a system sui genes.

\subsection{UNESCO}

UNESCO contributes to the protection of traditional knowledge through the safeguarding of the intangible cultural heritage. The definition of intangible cultural heritage contained in the Convention for the Safeguarding of the Intangible Cultural Heritage included customs, representations, knowledge and abilities, and associated tools, materials, artefacts and cultural spaces recognised by societies, groups and, in several cases, through people as part of their cultural legacy. Article 2 of the Convention contains examples of the spheres in which intangible cultural legacy is demonstrated: (a) oral traditions and forms of expression, including language as the bearer of intangible cultural heritage; b) performing arts; c) customs, rituals, festivities; d) knowledge and practices related to nature and the universe; f) knowledge and skills related to traditional crafts. Based on the above definition, we can conclude that intangible cultural heritage in the understanding of UNESCO includes, among other things, traditional knowledge (Gazizova, 2019).

The first UNESCO legal act to use the term "traditional knowledge" is the 2005 Convention on the preservation and growth of the variety of Cultural Expressions, the preamble of which identifies "the significance of traditional knowledge as a source of intangible and tangible heritage, and particularly knowledge systems of indigenous individuals, and their constructive aid to continual improvement, and the necessity to ensure their proper protection and promotion".

Currently, UNESCO is not faced with the task of protecting traditional knowledge and traditional cultural expressions from misuse and misappropriation. However, certain aspects related to the protection of traditional 
knowledge and traditional cultural expressions are also consolidated in the process of norm-setting in the field of safeguarding intangible cultural heritage and cultural diversity.

A number of issues related to the protection of traditional knowledge are touched in the activities of other international organisations: the World Trade Organization (WTO), the World Health Organization (WHO), and the Food and Agriculture Organization of the United Nations (FAO).

\subsection{WTO}

Within the framework of the WTO, discussions are underway on the possibilities of protecting traditional knowledge in accordance with the Agreement on Trade-Related Aspects of Intellectual Property Rights (TRIPS Agreement). Negotiations are underway on possible changes that need to be made to the Agreement in order to avoid conflicts with the Convention on Biological Diversity.

The TRIPS Agreement requirement to extend patenting to certain forms of "biological invention" causes a major criticism from many developing countries: "The TRIPS Agreement, as it stands, facilitates the granting of patents for products based on genetic resources and associated traditional knowledge, and does not contain sufficient provisions to preserve these resources and relevant understanding from misappropriation and theft. The lack of such provisions in the TRIPS Agreement may lead to arguments in its implementation and the implementation of the Convention on Biological Diversity" (WTO).

Nevertheless, issues of interest to developing countries continue to be ignored in the course of discussions on the TRIPS Agreement. The latest submission on this issue (WTO, 2011) in April 2011 proposed by the overwhelming majority of WTO Members, required the TRIPS Agreement to be amended to include a new Article 29 bis on the disclosure of the origin of genetic resources and / or associated traditional knowledge (WTO, 2018). However, no changes have been made so far, and discussions are still on-going.

\section{$3.4 \mathrm{WHO}$}

Since the goal of WHO is to achieve the highest possible level of health for all peoples, issues related to the protection of traditional knowledge are raised by this organisation in the context of traditional and complementary medicine, as well as public health. Traditional medicine is a medicine that is opposed to allopathic (conventional, Western) medicine. This determines that WHO's attention is focused specifically on traditional medical knowledge, and not on the entire body of traditional knowledge.

At the same time, the traditional medicine of indigenous peoples is defined as follows: it is a body of knowledge and practices, whether explicable or not and used to diagnose, prevent or eliminate physical, mental illnesses and diseases that pose a danger to society. This knowledge or practice can be based solely on past experience and observations passed down orally or in writing from generation to generation. Most often, local traditional medicine is practised at the primary health care level (WHO, 2019). However, WHO notes that the term "traditional medicine" refers to both traditional medicine systems such as traditional Chinese medicine, Indian Ayurveda and Unani Arabic medicine, and to various forms of indigenous medicine (WHO, 2001).

\subsection{FAO}

The FAO project "Conservation and Adaptive Management of Globally Important Agricultural Heritage Systems" is essential for the preservation of traditional knowledge. Globally Important Agricultural Heritage Systems (GIAHS) are preeminent land-use systems and landscapes that are rich in globally significant biodiversity resulting from the community's collaborative adaptation to the environment, and also the community's demands and passions for persistent improvement. Traditional knowledge and agricultural practices are one of the core elements of GIAHS. In turn, GIAHS plays an important role in the preservation of traditional knowledge and practices (FAO, 2018).

Currently, 57 sites in 21 states are recognised as globally important agricultural heritage systems, with their largest number in China and Japan. Examples include the Olive Groves of the slopes between Assisi and Spoleto in Italy, which are based on a traditional terrace management system that allows the cultivation of olive trees, and the Oasis of Gafsa in Tunisia, where plant cultivation has been made possible by using the knowledge of local communities about groundwater.

Certain aspects related to the protection of traditional knowledge and traditional cultural expressions have become the subject of international conferences: the Conference of the Parties to the Convention on Biological Diversity and the United Nations Conference on Trade and Development (UNCTAD). 


\subsection{Conference of the CBD Parties}

The activities of the Conference of the CBD Parties are focused on the protection of traditional knowledge associated with genetic resources. The Conference of the Parties developed an additional protocol to the Convention on Biological Diversity (Nagoya Protocol), as well as a number of advisory documents (Bonn Guidelines, Tkarihwaié:ri Code of Ethics, The Rutzolijirisaxik Voluntary Guidelines), which draw attention to the need for prior informed consent to gain access to traditional knowledge associated with genetic resources held by indigenous and local communities.

\subsection{UNCTAD}

UNCTAD addresses issues related to the protection of traditional knowledge in trade and development work. UNCTAD's main contribution to the protection of traditional knowledge and traditional cultural expressions is performed through research, business meetings and seminars at the regional and national levels encouraging the participation of indigenous and local communities, and promoting the development and implementation of integrated national strategies for using traditional knowledge for development and trade.

\section{Summary}

As follows from the above, the main activities related to the protection of traditional knowledge are currently carried out by WIPO and UNESCO. In recent years, WIPO has carried out extensive work and made considerable efforts to develop documents that can guarantee the efficient preservation of traditional knowledge and traditional cultural expressions. At the same time, UNESCO has done important and consistent work to ensure the preservation of cultural heritage, firstly tangible and then intangible.

Within the framework of the WTO, discussions are underway on the possibilities of protecting traditional knowledge in accordance with the TRIPS Agreement; negotiations are also underway on possible changes that need to be made to the Agreement in order not to conflict with the Convention on Biological Diversity. WHO analyses traditional medical knowledge from a health and innovation perspective. FAO conducts research related to Farmers' Rights, many of which relate to indigenous (or local) peoples. The Conference of the CBD Parties carries out activities aimed at resolving issues of prior informed consent and access to traditional knowledge associated with genetic resources. UNCTAD addresses issues related to the protection of traditional knowledge in trade and development work.

\section{Conclusion}

The concept of Traditional knowledge holds a tremendous significance to the international community. The prevalence of traditional knowledge can be observed in various fields, including medicine, agriculture, crafts, biological diversity and so forth. Furthermore, their diversity results in the fact that they become the subject of interest of many international organisations and conferences, each of which regards traditional knowledge based on their intentions and objectives. As a matter of fact, the protection of traditional knowledge is currently the subject of WIPO activity in its policy-making and rule-making. Hence, and it can be foreseen that the preservation of traditional knowledge will soon be organised under intellectual property law.

\section{Acknowledgements}

The work is done based on the Russian Government Program of Competitive Growth of Kazan Federal University.

\section{References}

Badaraev, D.D. (2016). Traditional economic practices of Mongolian-speaking nomads: cattle breeding in the adjacent territories of Mongolia and Russia. Bulletin of the Institute of Sociology, 3(18), 176-194.

Stepanova, D. I., Garnov, A. P., Brykin, A. V., \& Jancikova, E. (2019). Irrational behavior of youth when taking financial decisions. International Journal of Economics and Business Administration, 7, 378-387.

FAO. (2018). Report on the High-Level Regional Dialogue on the Mainstreaming of Biodiversity in the Agricultural, Forestry and Fisheries Sectors (DRANIBA). Mexico City, October 29-30, P. 7. http://www.fao.org/3/ca4924en/CA4924EN.pdf 
Gazizova, A.Sh. (2019). On the protection of traditional knowledge, traditional cultural expressions, and genetic resources. Russian legal journal, 2(125), 58-65. P. 60.

Gazizova, A.Sh. (2019). Role of UNESCO and WIPO in the international legal protection of traditional cultural expressions and traditional knowledge. Moscow Journal of International Law, 3, 81-92. P. 90.

Halupa, C.M., \& Caldwell, B.W. (2015). A Comparison of a Traditional Lecture-based and Online Supplemental Video and Lecture-Based Approach in an Engineering Statics Class. International Journal of Higher Education. $4(1)$.

WHO. (2001). Traditional Medicine Strategy in 2002-2005. WHO/EDM/TRM/2002.1. WHO, 62 p. https://apps.who.int/iris/bitstream/handle/10665/67163/WHO_EDM_TRM_2002.1_rus.pdf?sequence=5 p. 1

WHO. (2019). Global Report on Traditional and Complementary Medicine. WHO 2019, 226 p. https://www.who.int/traditional-complementary-integrative-medicine/WhoGlobalReportOnTraditionalAndCom plementaryMedicine2019.pdf?ua=1

WIPO. (2019). The Protection of Traditional Cultural Expressions: Draft Articles. WIPO/GRTKF/IC/40/5. Document of the Secretariat for the 40th Session of the Intergovernmental Committee on Intellectual Property and Genetic Resources, Traditional Knowledge and Folklore, Geneva, June 17 to 21, 2019. Date: April 9.

WIPO. (2019). The Protection of Traditional Knowledge: Draft Articles. WIPO/GRTKF/IC/40/4. Document of the Secretariat for the 40th Session of the Intergovernmental Committee on Intellectual Property and Genetic Resources, Traditional Knowledge and Folklore, Geneva, June 17 to 21, 2019. Date: April 9.

WTO. (2011). Draft Decision to Enhance Mutual Supportiveness Between the Trips Agreement and The Convention

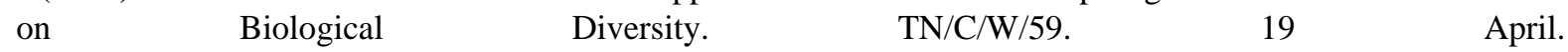
https://docsonline.wto.org/dol2fe/Pages/SS/DirectDoc.aspx?filename=t\%3A\%2Ftn\%2Fc\%2Fw59.doc\&

WTO. (2018). Index of The Statements Made at The Meeting of Council for TRIPS 5-6 June. IP/C/M/89/Add.1. https://docs.wto.org/dol2fe/Pages/FE_Search/FE_S_S009-DP.aspx?language=E\&CatalogueIdList=248052,246 136,244469,243778,243779,243545,241988,240401,239871,238630\&CurrentCatalogueIdIndex=0\&FullTextH ash $=\& H a s E n g l i s h R e c o r d=$ True $\& H a s F r e n c h R e c o r d=F a l s e \& H a s S p a n i s h R e c o r d=F a l s e$

WTO. The Relationship Between the TRIPS Agreement and the CBD and the Protection of Traditional Knowledge, Technical Observations on The United States Submission IP/C/W449 by Bolivia, Brazil, Colombia, Cuba, India And Pakistan. IP/C/W/459.

Wynberg, R., \& Chennells, R. (2009). Green Diamonds of the South: An Overview of the San-Hoodia Case' in: Wynberg R., Schroeder D., Chennells R. (Eds) Indigenous Peoples, Consent and Benefit Sharing: Lessons from the San-Hoodia Case. Springer, P.107.

\section{Copyrights}

Copyright for this article is retained by the author(s), with first publication rights granted to the journal.

This is an open-access article distributed under the terms and conditions of the Creative Commons Attribution license (http://creativecommons.org/licenses/by/4.0/). 